\title{
Communication Pattern of the Director of Regional Hospital in the implementation of Health Decentralization in Indonesia Case Study Pattern about Communication Director of Regional Hospital in Implementation of Government Regulation Number 18 Year 2016 at Karawang Hospital District
}

\author{
Siti Nursanti S. Sos..M.I.Kom \\ Doctoral Program Students \\ Communications Faculty of Padjdjaran University \\ Jl. Raya Bandung Sumedang, Hegarmanah, Jatinangor, KabupatenSumedang, Jawa Barat 45363 \\ sitinursanti@yahoo.com, siti16059@student.unpad.ac.id \\ Susane Dida Dr., MM, Prof., \\ Dr. Mien Hidayat, M.S, \\ Dr. IrvanAfriandi, dr., Grad, Dipl.OEH., MPH., PH \\ Lecture of Communication Faculty Padjdjaran University \\ Jl. Raya Bandung Sumedang, Hegarmanah, Jatinangor, Kabupaten Sumedang, Jawa Barat 45363
}

\begin{abstract}
This research discusses the communication pattern done by a director of a regional hospital in the process of health decentralization in Indonesia. Hospital is a unique institution because it has so many different health professionals who work there. After the enactment of government regulation Number 18 Year 2016 the hospital is no longer a regional technical institution but limited to a service unit under the Health Service Department. This study uses a qualitative paradigm with case study research methods where the several events were used as the object of research and being studied for a certain period of time. The research was in Kabupaten Karawang. In this study, four speakers have different views about the same case. This study aims to find out the pattern of a director's communication which in article 43 of government regulation No. 18 of 2016 is an additional task given to a doctor or dentist. In this study, we concluded that the post-decline autonomy law becomes a new chapter for decentralization in health. Unfortunately, this decentralization is not accompanied by the deconcentration of authority. The region does not feel the ownership of the health sector, especially hospitals. The funding responsibility for the hospital is located in the central government which requires a director to have a strong relationship with the central government. The work of directors does not only stop at reputable hospitals that have many subordinates with different backgrounds.
\end{abstract}

Keyword: Communication Organization, health communication, Communication Pattern Director

\section{INTRODUCTION}

Implementation of the bureaucratic reform by the government aims to realize the implementation of good governance. The Law No. 23 of 2014 on Regional
Government describes each of its articles about the regulation and the division of authority both the affairs of the Central Government, as well as the matters shared with the Regional Government. Currently, the region has implications in all areas by implementing Law no. 23 of 2014. One of them is the division of Government affairs between the central government, provincial government, and local governments which are embodied in the regional apparatus organizations.

The Central Government through the Ministry of Home Affairs of the Republic of Indonesia has issued Government Regulation No. 18 of 2016 on regional apparatus (PP No. 18 of 2016). Issued government regulation is the implementation of government to implement the provisions of Article 232 paragraph (1) of Law no. 23 In 2014. The government regulations mentioned above explain that the definition of regional apparatus is the element of the assistant to the regional head and the regional legislature in the implementation of the Government Affairs. It is the authority of the Regional Article 1 point 1 Government Regulation number 18 of 2016.

Furthermore, the provincial and district governments must implement the government regulation in the form of regulation namely the Regional Regulation as outlined in Article 3 paragraph (1) PP. 18 (2016). Therefore, the establishment of regional apparatus as regulated in this government regulation should be outlined in the form of regional regulations.

The previous regulation concerning the organization of regional apparatus as the base of the old Regional Government Law must be adjusted to the new local government law (Law No. 23 of 2014). It can be seen in the 
closing provisions of article 125 of Government Regulation No. 18 of 2016 which explains that at the time this Government Regulation comes into force, Government Regulation No. 41/2007 concerning regional apparatus organizations is revoked and declared null and void.

The hospital is a unique and very specific organization as an agency. There are not only the current doctor's profession but also many other professions working in hospitals such as pharmacists, nurse analysts, and others. The development of hospitals experienced a huge leap. In the global era and publication of the Public Hospital Openness Act, based on its guidance, hospital should not only perform excellent service but also become an open institution that can compete with other alternative medicine. Clear management is required for hospitals to be able to do it. Nowadays, so many laws and regulations of the new president issued by the government resulted in turbulence service in hospitals.

The progress of hospital development is currently undergoing significant changes where hospitals are in a global and competitive environment. Hospitals as health facilities are required to always maintain their quality by providing expected services to satisfy the community as recipients of services.

Professional management means carrying out control in an accountable way and done by trained people. Besides, it also means having a responsibility to provide the best service to the community. Maintaining the quality of service is the main thing that must be done by the whole range of hospital management.

The Regional Autonomy Law mandates the authority of the regions in the management of regional apparatus organizations. The role of the region is considered necessary considering the vast development of Indonesia.

History has noted that in the late 1970s, Indonesia decentralized health but was not accompanied by fiscal decentralization. As a result, there is no transfer of authority from the central government to the regions. This section examines whether budgetary decentralization policies works and seeks to understand the prospects for health development in the decentralization era.

Leadership is a universal phenomenon that affects the organization. An organization is strongly influenced by choice of leadership style chosen by a leader in managing the course of the organization he leads. The leader is one of the essential factors that affect the management of an organization. Leaders can either raise an organization or even destroy the organization. Communication has a necessary part in an organization in addition to exchanging messages within that also has a purpose of changing the behavior of individual members of the organization. A good organizational culture is determined by a competent leadership communication pattern so that organizational goals can be achieved well. The leadership style of a leader can determine the progress or decline of an organization. Hospital is a unique organization that consists of various professions such as doctors, nurses, midwives and other support staffs coming from different backgrounds. The doctor is one of the absolute requirements to become a leader or director of a hospital.

\section{LITERATURE REVIEW}

According to Blau and Scott (1962), work is the foundation for the classical structural theory of organization. They distinguish between the general structure of a social organization and the more specific structures called formal organizations. The hospital is an official organization that is formed and bound by rules of government. What happens within the organization is formally regulated by law, to establish a standardized organizational communication pattern.

The existence of a pattern or regularity in social interaction implies that there is a relationship between the person who transforms them from one set of individuals into groups of people or from some groups into a larger social system. Hospitals that comprise a variety of professions and are united with the same goal make a larger organization.

Berlo (1960) suggests that communication deals with social organization in three ways:

1. the social system is generated through communication. The uniformity of behavior and pressure to conform to norms is generated through communication among members of the group,

2. when the social system has developed, it determines the communication pattern of its member members. The social system influences how, to, from whom and by how communication affects the members of the system. The social status of a person in the system, for example, increases the likelihood of speaking to persons of equal status and reduces the possibility of communicatiing with persons with much higher or much lower status

3. knowledge of a social system can help us to make accurate predictions about people without knowing more than the role they play in the system.

The hospital as an organization that has very clear rules of legislation has a rigid bureaucratic character as a formal organization. All power in the organization is determined from behind the table and cannot be challenged because everything that happens in it has been regulated in such a way by the strict rules.

Mex Waber provides ten characteristics of the ideal bureaucratic organization:

1. An organization consists of relationships established by the position of office. 
2. Organizational goals or plans are divided into tasks; organizational tasks are channeled among various positions as official obligation.

3. Authority to perform obligations is given to the position.

4. Line lines of authority and office are governed through a hierarchical order.

5. A system of rules and regulations that are common but firmly defined formally, regulating the actions and functions of functions in the organization.

6. Procedure in organizations are formal and impersonal organization rules apply to individuals.

7. An attitude and procedure for applying a discipline system are part of the organization.

8. Members of the organization must separate the personal life and organizational life.

9. Employees are selected to work in organizations based on technical qualifications, instead of politic connections, family connections, and other connections.

10. Although the work in the bureaucracy is based on technical skills, promotion is based on seniority and work performance.

\section{Health Communication}

If we talk about health communication, we will inevitably have to link it with the concept of public health concept, especially the discussion about health information or health promotion. These last two issues, historically related to the various movements of health in society. Armstrong, Gleitman (1983)argues, there are four forms of public health movements that occurred between the years 1930-1991.

1. The quarantine movement is a movement to localize the infectious disease sufferers of a certain place or a closed place that is separate from the community (the general population) so that the disease is not transmitted to others.

2. Movement to improve knowledge about hygiene education movement that aims to teach knowledge about hygiene to the public so that citizens are more concerned about the cleanliness of the environment that results in keeping the source of the disease or prevent the body from being infected or contracting diseases from outside.

3. Individual health movement is a movement that requires every individual to supervise the contact between the body in public places such as schools, dormitories, market, port even in the hospital. This movement is pioneered by the government through regulation on the protection of individual health from time to time.

4. The movement introduces a new concept of public health in the field of public health, among others, by adopting the environmental hygiene that were originally intended only for individuals. For example, by extending the workshop agenda and the general public's awareness. The movement that emerged in the early 19th century was a movement of western society to prevent radiation, water pollution, work environment and others. This movement is related to green politics, city health, etc. as stated in the concept of Health for all 2000 . (Barbara Griffin, November 1998)

The world' health issues that get numerous attention.

1. Agreement on primary health care. The world's concern for "all" responsibility for public health has been outlined in various agreements. Agreements, or whatever its name by the world community that are aware that "we" are all responsible for public health.

2. Ottawa Conference. The same conference that was conducted in Alma Alta then took place in Ottawa also produced Ottawa charter for health promotion Health Promotion (1986) which, among others, advocated the provision of opportunities for efforts to increase public health monitoring and renewal through:

a. Build personal capability (self-ability to handle individual health).

b. Create support for the environment that is the creation of support from the community environment that is actively involved in handling the health of the individual community and the community altogether.

c. Reorientation of health services that is reorienting or reviewing various programs and activities related to public health.

d. Building mediation and advocacy. It builds various forces in society to undertake, mediate and advocate health to individual health programs involving the community and environmental participation.

e. Strengthen community action and role. The participants of the Jakarta conference agreed that from the various reports of participants coming from all over the world it is evident that our attention is still low in health promotion.

According to those points, it is considered that we should change the concept of health promotion strategy with a practical approach relevant to achieve equality of human health through:

1. A comprehensive approach to effective health development

2. The promotional strategy is to be directed to all places that include big and small towns in all cities, indigenous communities, public places such as schools, workplaces, and markets.

3. Participation of all parties so that we can together encourage everyone to become the center of health promotion. Consequently, each party can make their own decisions related to health. 
4. Learn to participate so that we can access health information together that is useful for knowledge and education to strengthen all people in society.

\section{METHOdology/Materials}

The research paradigm in this study uses naturalistic paradigms within the scope of the sociocultural tradition. Researchers naturally examine the existence of social and cultural research subjects, where communication is focused on social reality. One approach in science is the social sciences. Although the social science approach is an attempt to use the exact science approach given to society (August Comte), it introduces sociology as a science that discusses social life borrowed from physics. In attempting to observe and interpret patterns of human behavior, the roots of social science make the man an object of study to observe. If behavioral models are in fact present, then observation should be as objective as possible, in other words, social scientists such as natural scientists must establish a consensus on what is accurately observed which will be explained or interpreted.

Suwardi Endraswara in the book Method, Theory, Engineering, Cultural Research, 2006 interpreted Robert Friedrichs's idea on paradigm. He mentions paradigm as a fundamental view of a discipline on what the subject matter (subject matter) should be studied (a fundamental image a discipline has of its subject matter). Endraswara (2008) In looking at the phenomenon of political health communication after the application of Government Regulation No. 18 of 2016, the researchers try to think thoroughly, looking for a frame by the study of science communication that is naturalistic. Researchers are in a neutral position and look for a complete picture of the process of communication. The paradigm is a loose collection of logically shared assumptions, concepts, or propositions that direct the way of thinking and the way of research. Theoretical orientation or perspective is a way of looking at the world, what people assume about something important, and what makes the world work. The paradigm becomes a frame of mind in which contains the concept and map (map) of the study thoroughly.

Methods are the perspective and principles of thinking about the phenomena studied, the approach used, the scientific procedures (methods) followed, including in collecting data, data analysis, and conclusions. Bogdan and Taylor (1975: 1) briefly state the methodology as the process, principle, and procedure of how we perceive problems and seek answers.

Research to be conducted by researchers is a naturalistic research. According to Bajari (2012) Qualitative research or also called naturalistic research evolved along with knowledge about the flow of humanism as the root of explanation of human behavior. Sukidin (2002), citing Strauss and Corbin (1997) Qualitative Research is a type of research that results in discoveries that cannot be achieved by using statistical procedures or by other means of quantification. In qualitative research, there are four subjective assumptions about scientific truth or reality. Those assumptions are (1) Nominalism. Scientific truth is the result of construction that is given a liking by the individual, including the researcher; (2) Antipositivism. Scientific truth can only be understood from the perspective of the individual offender. (3) Voluntarism. Man is assumed to be an autonomous being fully and have "free will," that they actively and creatively live the reality; (4) Ideographic, the qualitative research seeks to understand and explain reality. They try to assemble and arrange patterns to discover something new or theory through the induction process scientific (inductive thinking method). Qualitative research is "theoretical gathering" by assembling and developing patterns of individual social action. (Bajari 2012).

The research method used by researcher is qualitative research method. Researchers view this research as interactive and minimize the level of subjectivity. A study that will be conducted by the researcher is political health communication after the application of Law no 18 (2016).

Qualitative Research by Yin (2011) in Bajari (2012) is defined as (1) Studying the meaning of living people in real-world conditions and situations; (2) Representing the views and perspectives of the community in research; Society is not an object of observation, but rather they provide a picture of the true reality of a fact to scientific truth; (3) Including the contextual conditions in which members of the living community (4) Contributing to the development of insights into existing or new concepts that can help to explain human social behavior, and (5) Striving to use multiple sources of data rather than relying on only one source. Qualitative research is known as a study that develops participatory field approaches.

In this study, researchers used the qualitative method with case study approach. Researchers think this method is very appropriate to be a way that can describe the phenomenon in the study of political communication health after the application of Law No. 18 of 2016. As described by Geertz (1988), thick description, I is about the complex processes and their influence in a particular context. The ability to provide rich portraits in this way is a crucial benefit of case studies. Your research reader should be made to feel as if they were there with you in your research, see what you see, and summarize what you have concluded.

According to Patton the process of preparing the case study takes place in three stages. The first phase is the collection of raw data about individuals, organizations, programs, locations of incidence that the basis of writing case studies. The second step is to compile or arrange cases that have been obtained through compacting, summarizing data that is still in the form of raw data, classifying and editing and inserting it in one file that can be set to become manageable 
and accessible. The third step is writing the final report of a case study in the form of narration.

In qualitative research, researchers naturally view the problem in the context of the study. The researcher plunged into the events and conditions that occur in the context of research. Researchers are directly involved in the field on various sides of events that occur when the observation process takes place. According to Bajari Qualitative Research demands a high level of extinction. An intensive researcher goes into a community to get a complete picture of a situation or experience. Pretending becomes the "ultimate weapon" to "hide" identity as a researcher. It is done to get the accurate data, not to give intervened feeling because they are being researched. Besides, it also attempts to construct opinions and behavior descriptions of key informant sunglasses in full. This effort can only succeed if the researcher establishes a relationship that can be accepted by the informant.

According to Stake (1995), case study is a research strategy in which researchers carefully investigate a program, event, activity, process, or group of individuals. Cases are limited by time of activity. Researchers collect complete information using various data collection procedures based on the time specified.

The case study approach, according to the researcher, is a possible way to describe and explore the phenomenon seen in health politics communication after the adoption of government regulations no 18 of 2016. Raco explained this case study could help researchers to conduct an in-depth study of individuals, groups, programs, organization, cultural, religious, regional or even state. Understanding special cases that occurred in the past will help individuals, communities, and communities to understand and address the issues at hand or to be faced.

According to Yin (2013) provides more technical limitations with an emphasis on its characteristics. Ary, Jacobs, and Razavieh (1985) explained that in case studies, the researcher should try to test the unit or individual in depth. The researchers tried to find all the variables that are important in the study. Based on these restrictions, it is understandable that case study limits include (1) the target of his research may be human, event, background, and document; (2) those goals are examined in depth as a totality according to their respective backgrounds or contexts in order to understand the various links that exist between the variables.

\section{RESULTS AND FINDINGS}

Health concerns are provided in Article 12 Paragraph (1) which explains that the Compulsory Government Affairs relating to Basic Services include: education, health, public works and spatial arrangement, public housing and settlement areas, peace, public order, and social and social protection. This article increasingly affirms that health affairs are still a matter of local government's obligatory. The most striking difference in the health sector since the era of autonomy is the change of civil servant employment status in the health from health department employees to local civil servants.

Substantially, however, the decentralization of health concerns has left some of the following issues:

1. Regional political interests still appear in the management of hospitals

2. The choice of the head of the health office and the hospital will be have much political nuance because the leader is in the realm of political office

3. The emergence of the issue that the hospital is the largest producer of regional income before the release of the regulation of the management of regional public service agencies

4. Health field has two different 'mothers'. On one side, they must follow the provisions of bureaucracy, but on the other hand, they must obey the provisions of the minister of health

5. Human resource standards are strictly regulated by the ministry of health, but there is no standard of income for health workers, especially doctors

6. Ministry of Health as the regulatory providers to be obeyed by all parties related to the health domain sometimes have rules that clash with local regulations

The emergence of a very complicated issue is in Article 95 Paragraph (8) as follows:

Head of Technical Implementing Unit of Regency / Municipality Region in the form of a hospital. The district/municipality is held by a doctor or dentist designated as a functional official of a doctor or dentist additional task

In the elucidation of Article 95 Paragraph (8), it is stated that what is meant by "functional officer of doctor or dentist" is including a specialist doctor and dentist specialist who occupy an operative position of doctor and dentist.

In Bahasa Indonesia Dictionary (Kamus Besar Bahasa Indonesia, KBBI) the term 'additional' means an extra or supplementary attachment, meaning that the additional task is only a complementary task in addition to the main task. In short, that is only a side job so it can be done casually or on the sidelines doing the primary task. Therefore, a physician or dentist appointed to be the director of RSD will perform the duties as director "on the sidelines" of his primary responsibility as a functional employee (provide services to patients). For example, a doctor will provide services to patients from 08.00 am to $12.00 \mathrm{pm}$ and after $12.00 \mathrm{pm}$ will perform the function as a director before going home. Or on the sidelines between the 08.00 am and $14.00 \mathrm{pm}$, he/she still have the role as a director like signing incoming letters, giving disposition and so forth.

Then, by looking at the description of the norm, the head of the provincial technical implementation unit in the 
form of a Provincial Hospital is held by a doctor or dentist designated as a functional official of a doctor or dentist with an additional assignment. Afterwards, understanding the meaning of the "additional task" must be within the context of a physician as a functional official who is also responsible as the Head or Director of the Technical Implementation Unit of the Regional Hospital. Hence, their main responsibility is still to be the doctor or dentist.

Also, it is essential to understand the issue of the norm formula in P 94 (9) and P 95 (8), that it is indispensable from the provisions of P 21 and P 43 PP 18/2016, namely that hospital area has been determined as a functional organizational unit. This change of institutional paradigm cannot be separated from the legal ontology philosophy of regional autonomy. The granting of the broadest autonomy is not aimed at the regional institutional aspect but directed to accelerate the realization of community welfare. One of them is through the improvement of service to the community as the focus. Even the institutional paradigm of local government desired by the state through Act 23/2014 is the right sizing, the principle of proper function and proper size.

\section{References}

Armstrong, S. L., et al. (1983). "What some concepts might not be." Cognition13(3): 263-308.

Bajari, A. (2012). Anak jalanan: dinamika komunikasi dan perilaku sosial anak menyimpang.

Berlo, D. K. (1960). "The process of communication: An introduction to theory and practice."

Blau, P. M. and W. R. Scott (1962). Formal organizations: A comparative approach, Stanford University Press.

Bungin, B. (2006). "Sosiologi Komunikasi: teori, paradigma dan diskursus teknologi komunikasi di masyarakat."

Bungin, B. (2007). "Penelitian Kualitatif: Komunikasi, Ekonomi, Kebijakan Publik dan Ilmu Sosial Lainnya."

Creswell, J. W. (2012). Qualitative inquiry and research design: Choosing among five approaches, Sage publications.

Daymon, C. and I. Holloway (2010). Qualitative research methods in public relations and marketing communications, Routledge.

Endraswara, S. (2008). Metodologi penelitian sastra, Niaga Swadaya.

Geertz, C. (1988). Works and lives: The anthropologist as author, Stanford University Press.

Pace, R. W., et al. (2006). Komunikasi organisasi: strategi meningkatkan kinerja perusahaan, PT Remaja Rosdakarya.

Pawito (2009). Komunikasi politik: media massa dan kampanye pemilihan, Jalasutra.

Raco, J. R. (2010). "Metode penelitian kualitatif: jenis, karakteristik dan keunggulannya." Jakarta: Grasindo.

Sukidin, B. (2002). "Metode Penelitian Kualitatif Perspektif Mikro." Insan Cendekia. Surabaya.

Yin, R. K. (2013). Case study research: Design and methods, Sage publications. 